\title{
The Role Of Human Resources In Strengthening The Creative Industry During The Covid-19 Pandemic
}

\section{Christian Wiradendi WOLOR ${ }^{1^{*}}$, Usep SUHUD ${ }^{2}$, Ahmad NURKHIN ${ }^{3}$, Yudin CITRIADIN ${ }^{4}$}

\author{
${ }^{1}$ Faculty of Economics, Universitas Negeri Jakarta, Indonesia. ORCID id: 0000-0003-1314-9966, \\ E-mail: christianwiradendi@unj.ac.id \\ ${ }^{2}$ Faculty of Economics, Universitas Negeri Jakarta, Indonesia. ORCID id: 0000-0002-1728-0737 \\ ${ }^{3}$ Faculty of Economics, Universitas Negeri Semarang, Indonesia. ORCID id: 0000-0003-4743-1134 \\ ${ }^{4}$ Faculty of Tarbiyah and Education, Universitas Islam Negeri Mataram, Indonesia. ORCID id: 0000-0002-3510-8631 \\ ${ }^{*}$ Corresponding Author
}

\begin{abstract}
Received: 06.06.2021
Accepted: 12.08.2021 Published: 26.10.2021

DOI: 10.47750/QAS/22.184.04
\end{abstract}

\begin{abstract}
The creative industry is a central part of the global trade movement in the creative economy, thus creating a network of collaborations and talents around the world. However, during the COVID-19 pandemic, many industries experienced setbacks and were affected. This study aims to understand and explore information related to the role of human resources in strengthening the creative industry during the COVID-19 pandemic. The unit of analysis in this study is the business actor of the Batik fashion creative industry group located in Pekalongan which was appointed as a Creative City by UNESCO. This research uses a qualitative approach with a case study method, both in the process of data collection and analysis. Observations and semi-structured interviews were used to obtain information. The results of the study found that the Pekalongan batik business actors who are known as creative cities have not lost their creativity to continue to produce works and survive without losing the elements of local culture.
\end{abstract}

Keywords: Creativity, Culture, Risk-Taking Propensity, Creative Industry

\section{Introduction}

The creative industry may be familiar, which can move the economy of a country through job creation and increased exports. The creative industry sector can be said to have very crucial importance among the sectors of new types of economic activity, culture, and technological progress. The form of the creative economy is creativity and innovation between art, culture, trade, science, and technology (Daubaraitè \& Startienè 2015; Martinaitytė \& Kregždaitè, 2015).

However, during the COVID-19 pandemic, many companies experienced setbacks and were also affected by this pandemic. Indonesia did not escape the impact of this pandemic, which was marked by the recession that occurred in Q3 2020 where economic growth contracted by $3.49 \%$. Losses experienced by several companies have an impact on business closures, layoffs and in general, the country's economic growth declines. The economic downturn does not only occur in Indonesia but has spread globally (Akhlas, 2020; Harper, 2020). Most of the creative industry sector does depend on the audience, space, place, and experiences that involve physical proximity such as events, films, music festivals, exhibitions, culinary, of course, has an impact on decreasing economic transaction activities in the creative industry (Harper, 2020; Meithiana, 2020).

Of the 17 sub-sectors under the creative economy category,
3 sub-sectors have high foreign exchange contributions to Indonesia's Gross Domestic Product (GDP), namely, fashion, culinary and craft products (Catriana, 2020). This research takes place in Pekalongan focusing on "Batik" fashion. The choice of the city of Pekalongan was because the City of Pekalongan was named by the United Nations Educational, Scientific and Cultural Organization (UNESCO) as the World's Creative City for the category of Crafts and Folk Arts, namely "Batik" (DPMPTSP, 2021).

The creative city itself is a central part of the global trade movement in the creative economy, to create a network of collaborations and talents around the world. The emergence of creative cities will increase dynamism in related sectors (Sousa, Nunes, \& Monteiro, 2019). This has become a challenge for batik businesses in Pekalongan, which has been treated by UNESCO as a creative city in the face of the COVID-19 pandemic. Judging from the statistical data of tourist arrivals, there was a significant decrease in the number of tourists, both local and foreign tourists. Total foreign tourist visits to Indonesia in 2020 amounted to 4.02 million visits. When compared to 2019, the number of foreign tourists decreased by 75.03 percent (BPS, 2021). With a decrease in the number of tourists who come, it will affect the decline in sales and have an impact on the continuity of the batik business in Pekalongan. 


\begin{tabular}{|l|l|l|}
\hline \multirow{2}{*}{ Month } & \multicolumn{2}{|l|}{ Number of Tourist Visits } \\
\cline { 2 - 3 } & 2019 & 2020 \\
\hline January & $1.201,7$ & $1.272,1$ \\
\hline March & $1.311,9$ & 471 \\
\hline June & $1.434,1$ & 158,3 \\
\hline September & $1.388,7$ & 151,3 \\
\hline December & $1.377,1$ & 164,1 \\
\hline
\end{tabular}

Table 1: Number of Tourist Visits (In Thousands)

Source: BPS (2021)

This is coupled with, on average, business actors in Indonesia, especially MSMEs, have problems with digital access, including Batik business actors. This is of course needed because the future of this creative industry is quite promising and can become an economic source with high value because in this industry there is the content of ideas, art, innovation, technology, and intellectual property especially during the covid-19 pandemic which prohibits people from to crowd (Rachmawati, 2020; Setiaji, 2020; Trismiyanto, Sule, Joeliaty, \& Yunizar, 2018).

From the government side, the Government of Indonesia has officially launched the Pre-Employment Card program as a supplement in helping Indonesian human resources to improve their skills. Everyone who is accepted into this education program will receive funds from the government of Rp. 3.55 million as a solution in improving human resource skills amid rampant layoffs during the COVID-19 pandemic (Meithiana, 2020). Although in practice, not all business actors have received it, this is a motivation and supplement for business actors to learn how to develop their skills in terms of production, digital marketing which can later increase productivity.

It can be said that humans are the single element that competition cannot imitate. The intellectual capital, knowledge, and competence of employees will have an impact on the success or failure of this industry. Almost all products offered by the sub-creation industry sector depend on orders, people's tastes, and trends. This of course includes the creativity and innovation of the workers in it to produce good products. The results of successful human resource management are increased profits, productivity, market share, increased customer and employee satisfaction, and improved reputation.(Alexandri, Maulina, Chan, \& Widya Setiabudi Sumadinata, 2019; Cerani \& Popovi, 2008; Jodi, Sudjadi, \& Anggraeni, 2019).

From the point of view of the creative economy, there is a close relationship between creativity and inseparable socioeconomic development. Creative is formed and strengthened by human capital that generates and operates new economic resources. A person's ability to find new things, think critically, dream far ahead and always ask questions about a job shows that someone has creativity. Creativity includes many different forms. We will not know the culture if there is no difference. Creativity will create a feeling of pleasure for all stakeholders, whether by artists, scientists, or business executives (Petrović Milićević, \& Sofronijević, 2017). The creative economy is driven by ideas (intangible assets) as the main capital, while the industrial economy is driven by tangible assets (Hidayat \& Asmara, 2017). Creativity by its very nature produces variety, and it transforms individuals, organizations, and the economy as a whole. Creativity dramatically contributes to product and service differentiation and is often required in terms of customization (Petrović et al., 2017).

Research conducted by Bocella says that strengthening the creative industry requires the development of territorial networks, and policies to support local economies and interprivate relations, as well as between the public and private sectors. (Boccella \& Salerno, 2016). Traditional creative industries alone are not enough to meet the challenges, they must also understand how business skills and business models can be applied to create more valuable and creative products (Kiling, 2019).

This research is very important to study because at this time the creative industry is slowly starting to rise from adversity due to the covid-19 pandemic. This study also aims to understand and explore information related to the role of human resources in strengthening the batik creative industry in strengthening creative industry during the COVID-19 pandemic.

\section{Literature Review}

The creative economy is a concept, while the creative industry is the activity of the concept (Yulisetiarini et al., 2019). Creative industries include the arts and culture industries, both living and those produced as a whole, including goods and services produced which contain artistic or creative endeavors (Boccella \& Salerno, 2016; Martinaitytė \& Kregždaitė, 2015). The difference between the creative industry and the cultural industry is that the orientation of the creative industry is related to profit, while the cultural industry is related to national identity and the preservation of cultural heritage (Daubaraite \& Startienè, 2015). Many authors argue that all creative industry models can be reduced, enlarged or modified, but the essence of the model, above all, proves a very important idea. The idea is that creativity is ultimately recognized by the public as an economic value. The creative industry is a new engine for economic growth, wealth creation, and can present potential economic value for job creation (Alexandri et al., 2019; Kontrimienè \& Melnikas, 2017).

The process of creating something unique and novel that can be accepted and useful by society is creativity (Jodi et al., 2019). The development of new ideas, new solutions in problem-solving and always seeing opportunities is part of creativity. Therefore, as an entrepreneur, it is important to have creativity in running his business. A person is only labeled as an ordinary trader, not as an entrepreneur if he does not have creativity (Kusmintarti, Asdani, \& Riwajanti, 2017; Sousa et al., 2019). Creativity is an activity related to the formulation of new ideas related to products, services, processes, practices, management, business models, or competitive strategies. An idea is said to be creative if the idea is a new idea for the organization and work, it also has value and usefulness for making improvements or solving problems (Jodi et al., 2019).

Empirical studies have discussed the role of environmental support in developing creativity and entrepreneurship in the form of increasing one's creative capacity. One of them is that community culture plays an important role in influencing the creativity and entrepreneurial attitude of individuals living in that society. Becoming an entrepreneur is inseparable from the support of social factors, especially in forming creative ideas, joint problem solving, critical thinking, group unification, needed resources, and the presence of a new generation (EISaid \& Fuentes Fuentes, 2019). The cultural environment of some 
countries influences entrepreneurial behavior either by encouraging or preventing it. Favorable cultural attitudes towards entrepreneurship and high entrepreneurial status have important implications. The positive attitude of society towards entrepreneurship motivates people to start new businesses. Social factors, customs, norms, and culture that exist in society play an important role in shaping entrepreneurial intentions. This will create something unique and different from other areas. (Ozaralli \& Rivenburgh, 2016). The growing relevance in the field of entrepreneurship in the arts and culture is closely related to the emergence of the creative industry (Hausmann \& Heinze, 2016).

In addition to creativity and cultural factors, the attitude of daring to take risks is one of the key factors for business actors to survive. The type of risk-taker is always associated with someone who has an entrepreneurial spirit. This is supported by the results of research conducted by Ozaralli that high entrepreneurial intentions tend to have large risk-takers (Ozarall \& Rivenburgh, 2016). Entrepreneurs often face a risk-taking dilemma (Guo \& Jiang, 2020). Risk-taking refers to the tendency to engage in behavior that is potentially harmful or harmful, but at the same time provides opportunities for certain types of outcomes that can be considered positive. Entrepreneurs in creative fields build creative jobs by risk-taking by new and creative ideas (Allah \& Nakhaie, 2011). Entrepreneurs need to take risks, as this shows their openness to change, including new ways of working. Entrepreneurs who dare to take risks have a chance to succeed (Games \& Rendi, 2019).

\section{Methodology}

This study uses a qualitative approach to help researchers understand people and what they say and do (Idrus \& Priyono, 2014). The research method used is a case study, both in the process of data collection and analysis. This method is used to explore information about a person, social setting, event, or group that allows the researcher to understand how the process takes place and functions (Kurniadi, 2011).

The unit of analysis in this study is the business actor of the Batik fashion creative industry group located in Pekalongan. The number of participants in this study was 10 participants. The location determination was carried out purposively with the consideration of how the Batik business in Pekalongan as a UNESCO Creative City in the World can survive. The time of the research was carried out in January-March 2021.

The data analysis step used in this study is the Analysis Interactive Model starting from data collection, data reduction, data presentation, and drawing conclusions or verification (Miles \& Huberman, 2014). The data validity technique used in this study is triangulation to obtain more accurate and credible data findings and interpretations (Miles \& Huberman, 2014; Sugiyono, 2013). This makes it possible to trace data from interviews with data from documents, or data from two different research methods (Idrus \& Priyono, 2014).

To provide a clear picture of how creativity, the attitude to dare to change, and the cultural environment play an important role in the creative economy in the city of Pekalongan during the covid-19 pandemic, the researchers conducted observations and interviews by asking semi-structured questions without limiting the answers from participants. The research questions are:

a. What forms of creativity are you doing during the COVID-19 pandemic in maintaining the continuity of this business?

b. What positive impact did you get from the local cultural environment in running this business, especially during the COVID-19 pandemic?

c. How much risk do you take in making decisions to maintain the continuity of your business during the covid-19 pandemic?

The participants were 10 people who became batik business actors in Pekalongan.

\begin{tabular}{|l|l|l|l|l|}
\hline No. & Partisipant & Age & Sex & $\begin{array}{l}\text { Length of business } \\
\text { (In Years) }\end{array}$ \\
\hline 1 & Partisipant A & 40 & M & 15 \\
\hline 2 & Partisipant B & 61 & W & 35 \\
\hline 3 & Partisipant C & 39 & W & 9 \\
\hline 4 & Partisipant D & 52 & M & 26 \\
\hline 5 & Partisipant E & 47 & M & 18 \\
\hline 6 & Partisipant F & 36 & M & 7 \\
\hline 7 & Partisipant G & 49 & W & 23 \\
\hline 8 & Partisipant H & 55 & M & 29 \\
\hline 9 & Partisipant I & 42 & W & 16 \\
\hline 10 & Partisipant J & 35 & W & 7 \\
\hline
\end{tabular}

Table 2: Participant Data

\section{Results and Discussion}

The process of batik requires tenacity, expertise, and patience. Batik processing time varies greatly depending on the quality of the materials used, the level of difficulty of the motifs being done manually, to the time it takes for the batik cloth to be finished and ready to be used. This is what causes batik to be of high value, high value, and even enjoyed by not only Indonesians but also abroad. However, the Covid-19 pandemic has become a challenge for batik business people in Pekalongan. Although the scale is limited, the data sources yield a rich and interesting variety of findings. These findings refer to the research question.

\section{The form of creativity of batik creative industry business actors during the covid-19 pandemic}

The results of interviews between participants and researchers that participants must have creativity in dealing with the COVID-19 pandemic so that the batik business can survive. Participants revealed what they knew about the importance of creativity in creating a new idea to survive the economic downturn due to the COVID-19 pandemic. Participants revealed that with the emergence of the COVID-19 pandemic, they suffered from a decrease in the number of tourists to the creative city of Pekalongan due to restrictions on several areas. One 
participant said that "We must have creativity with new fashion models such as bags, dolls, wallets, and even masks with batik motifs." Creativity itself appears related to what is considered new by someone other than the originator, or as the use of ideas. Without creativity, one cannot survive the dynamic changes that occur (Kusmintarti et al., 2017; Sousa et al., 2019).

Another participant said, "Creating novelties that have never existed before is a form of creativity. One of them is by combining modern contemporary motifs with conventional batik." This is following Patten's research which states that creative people often show contrasting qualities that are considered productive, become the center of a series of activities, and can draw inspiration from various social groups. (Patten, 2016). Creative people can accept change and novelty, willingness to play with ideas and possibilities, the flexibility of outlook, good enjoyment habits while looking for ways to improve them (EISaid \& Fuentes Fuentes, 2019). Another participant said, "Creativity in marketing is also important even though it is only selling batik by organizing virtual exhibitions, online sales, batik making workshop tours." It is clear that it is not the only product that is a concern for batik business actors, but how the products that have been innovated can then be known and reached the hands of consumers.

If we see here, that people become more creative when they feel motivated mainly by interest, satisfaction, and challenging situations to solve problems that cannot be solved by others. (Okpara, 2007). Motivation, critical thinking, and having expertise are functions of the creativity that exists in each individual (Sousa et al., 2019). Pekalongan batik entrepreneur shows his motivation, namely the drive to survive and provide for his family. The second function, namely critical thinking, is by making contemporary motifs, making batik masks. The third function is to have expertise that technically they have been handed down from generation to generation from their family and environment.

\section{The impact of the community's cultural environment on the batik creative industry during the covid-19 pandemic}

The results of interviews between participants and researchers, namely the cultural environment that is rooted from generation to generation have an impact on the strength of business actors to face the impact of the COVID-19 pandemic. One participant said that "Batik activities are passed down from generation to generation from the family so they will continue to survive with the batik business." Previous research stated that culture influences entrepreneurial intentions through norms, social judgments, and growing out of family values (Bhansing, Hitters, \& Wijngaarden, 2017; Ozaralli \& Rivenburgh, 2016).

Another participant said that "There is a batik community in Pekalongan to maintain cultural heritage." This opinion was then supported by another participant who said that "The batik community in Pekalongan strengthens each other to share information in dealing with the COVID-19 pandemic, starting from the development of motif designs, batik exhibition info, to online marketing." Eroglu's research suggests that a culture that values and values such behavior will encourage a tendency to develop and introduce radical innovations (Eroglu \& Picak, 2011). Culture becomes very important because it represents one of the alternatives or 'outdoors' for product and service differentiation that can be offered by many transforming communities when interacting with global markets. (de Miranda, Aranha, \& Zardo, 2009)

Preservation of culture between generations is very important and becomes a legacy for mankind (Moscoso, Ramirez, \& Andrade, 2014). Culture is a source of creativity and innovation for humans as a source of income and employment. The Pekalongan batik business is no exception. Local culture is also an economic potential for the country. Besides business actors benefit from expanding their business abroad through exports, but also for the country as a foreign exchange earner.

\section{The attitude of the risk-taking propensity of batik creative industry business actors during the covid-19 pandemic}

The results of interviews between participants and researchers, namely the attitude of risk-taking propensity are essential to face the impact of the COVID-19 pandemic. One participant stated that "Risk-taking propensity is mandatory because of household needs and employees who must be paid a salary. Continue to produce even though it is not as optimal as it was before the COVID-19 pandemic." In line with the opinion of participants, that entrepreneurship is always associated with risk-taking (Ozaralli \& Rivenburgh, 2016). A risk-taking orientation has been considered a hallmark of the entrepreneurial and entrepreneurial process for a long time.

Another participant stated that "Changing motifs to suit modern styles, making batik masks is a way to take risks during the COVID-19 pandemic to survive." In line with this opinion, another participant said that "Providing discounted prices, selling online is a form of risk-taking in continuing to do business. Even though the gain is not much, it is often a loss."

The risk-taking by business actors refers to the tendency to engage in behavior that is potentially harmful or harmful, but at the same time provides opportunities for certain types of outcomes that can be considered positive. One form is risktaking by new and creative ideas (Allah \& Nakhaie, 2011). In line with the opinion of the participants above that previous research found that risk-taking has a positive effect on product innovation. Some researchers say that the dimensions of risk-taking and entrepreneurial orientation proactivity are the main predictors that can show product or service innovation and business performance (Guo \& Jiang, 2020; Tresna \& Raharja, 2019).

Entrepreneurs need to take risks, because it shows their openness to change, including new ways of working. This needs to be done so that they can survive even though there is a risk that will worsen their condition. However, entrepreneurs who dare to take risks also have a chance for success. Risk-taking requires the entrepreneur's willingness to devote significant resources to reasonable odds, or failure at a cost, as well as a willingness to disengage from the avenue that has been tried. Therefore, the risk-taking taken by entrepreneurs needs to be taken into account regarding the positive and negative impacts that will be experienced.

Although not much research has been done on the impact of the COVID-19 pandemic related to human resources relations in the creative economy perspective. This study shows that there is a relationship between creativity, the cultural environment, and the attitude of risk-taking propensity in dealing with the negative impacts of the COVID-19 pandemic.

\section{Conclusion}

The city of Pekalongan, which was crowned by UNESCO with its famous creative economy, namely batik, has not been spared the impact of the COVID-19 economic downturn due to many countries implementing lockdowns and several regions implementing PSBB (Large-Scale Social Restrictions). However, the results of this study indicate that the Pekalongan batik business actors who are known as creative cities have not lost their enthusiasm to continue to produce and produce batik handicrafts in various ways from production to marketing. This 
can be seen from batik business actors who continue to produce even though they perform employee efficiency, renew batik motifs following modern trends without eliminating the elements of Pekalongan culture, producing market needs, namely batikpatterned masks, contemporary batik motifs, and conducting online sales and virtual exhibitions. This is done so that they can survive, household needs that must be met, and workers who must be supported.

\section{References}

[1] Akhlas, A. W. (2020, November 5). Breaking: Indonesia enters first recession since 1998 on $3.49 \%$ Q3 contraction. The Jakarta Post. Retrieved

from https://www.thejakartapost.com/news/2020/11/05/breakingindonesia-enters-first-recession-since-1998-on-3-49-q3contraction.html

[2] Alexandri, M. B., Maulina, E., Chan, A., \& Widya Setiabudi Sumadinata, R. (2019). Creative industries: Existence of arts traditional industries in Indonesia. Academy of Strategic Management Journal, 18(1).

[3] Allah, M. A., \& Nakhaie, H. (2011). Entrepreneurship and risk taking. In 2011 International Conference on E-business, Management and Economics (Vol. 25). https://doi.org/10.1111/j.1464-0597.2009.00402.x

[4] Bhansing, P. V., Hitters, E., \& Wijngaarden, Y. (2018). Passion Inspires: Motivations of Creative Entrepreneurs in Creative Business Centres in the Netherlands. The Journal of Entrepreneurship, 27(1), 1-24. doi:10.1177/0971355717738589

[5] Boccella, N., \& Salerno, I. (2016). Creative Economy, Cultural Industries and Local Development. Procedia - Social and Behavioral Sciences, 223, 291-296. doi:10.1016/j.sbspro.2016.05.370

[6] BPS. (2021). Jumlah Kunjungan Wisman ke Indonesia. Retrieved from

https://www.bps.go.id/pressrelease/2021/03/01/1797/jumlahkunjungan-wisman-ke-indonesia-bulan-januari-2021-mencapai141-26-ribu-kunjungan.html

[7] Ceranic, S., \& Popovic, B. (2009). Human resources management in small and medium enterprises. Applied Studies in Agribusiness and Commerce, 3(1-2), 71-74. doi:10.19041/apstract/2009/1-2/8

[8] Daubaraitè, U., \& Startienè, G. (2015). Creative Industries Impact on National Economy in Regard to Sub-sectors. Procedia - Social and Behavioral Sciences, 213, 129-134. doi:10.1016/j.sbspro.2015.11.415

[9] De Miranda, P. C., Aranha, J. A. S., \& Zardo, J. (2009). Creativity: people, environment and culture, the key elements in its understanding and interpretation. Science and Public Policy, 36(7), 523-535. doi:10.3152/030234209x465552

[10] DPMPTSP. (2021). Pekalongan Kota Kreatif Dunia. Retrieved from https://oss.pekalongankota.go.id/index.php/id/kotapekalongan/sekilas-kota-pekalongan/pekalongan-kota-kreatifdunia

[11] EISaid, O. A., \& Fuentes Fuentes, M. del M. (2018). Creative Thinking and Entrepreneurial Attitudes Among Tourism and Hospitality Students: The Moderating Role of the Environment. Journal of Hospitality \& Tourism Education, 31(1), 23-33. doi:10.1080/10963758.2018.1480963

[12] Eroglu, O., \& Picak, M. (2011). Entrepreneurship , National Culture and Turkey. International Journal of Business and Social Science, 2(16), 146-151.

[13] Games, D., \& Rendi, R. P. (2019). The effects of knowledge management and risk taking on SME financial performance in creative industries in an emerging market: the mediating effect of innovation outcomes. Journal of Global Entrepreneurship Research, 9(1). doi:10.1186/s40497-019-0167-1

[14] Guo, Z., \& Jiang, W. (2019). Risk-taking for entrepreneurial new entry: risk-taking dimensions and contingencies. International
Entrepreneurship and Management Journal, 16(2), 739-781. doi:10.1007/s11365-019-00567-8

[15] Harper, G. (2020). Creative industries beyond COVID-19 Creative Industries Journal, 13(2), 93-94. doi:10.1080/17510694.2020.1795592

[16] Hausmann, A., \& Heinze, A. (2016). Entrepreneurship in the Cultural and Creative Industries: Insights from an Emergent Field. A Journal of Entrepreneurship in the Arts, 53(9), 16891699.

[17] Hidayat, A. R. T., \& Asmara, A. Y. (2017). Creative industry in supporting economy growth in Indonesia: Perspective of regional innovation system. IOP Conference Series: Earth and Environmental Science, 70, 012031. doi:10.1088/17551315/70/1/012031

[18] Idrus, M. ., \& Priyono. (2014). Penelitian Kualitatif Di Manajemen \& Bisnis. (R. P. Suci, Ed.). Sidoarjo: Zifatama.

[19] Jodi, N. S., Sudjadi, A., \& Anggraeni, A. I. (2019). The role of creativity in forming innovative behaviours of creative industrial workers. International Journal of Innovation, Creativity and Change, 9(11), 166-178.

[20] Kiling, N. (2019, October 1). Industry 4.0 vs creative sector: Disruptive or constructive? Jakarta Post. Retrieved from https://www.thejakartapost.com/life/2019/10/01/industry-4-0-vscreative-sector-disruptive-or-constructive.html

[21] Kontrimienè, V., \& Melnikas, B. (2017). Creative Industries: Development Processes Under Contemporary Conditions of Globalization. Business, Management and Education, 15(1), 109-126. doi:10.3846/bme.2017.340

[22] Kurniadi, B. D. (2011). Praktek Penelitian Kualitatif: Pengalaman dari UGM. Yogyakarta: Research Centre for Politics and Government.

[23] Kusmintarti, A., Asdani, A., \& Riwajanti, N. I. (2017). The relationship between creativity, entrepreneurial attitude and entrepreneurial intention (case study on the students of State Polytechnic Malang). International Journal of Trade and Global Markets, 10(1), 28. doi:10.1504/ijtgm.2017.082379

[24] Martinaitytè, E., \& Kregždaitè, R. (2015). The factors of creative industries development in nowadays stage. Economics \& Sociology, 8(1), 55-70. doi:10.14254/2071-789x.2015/8-1/5

[25] Meithiana. (2020, November 25). Menyelamatkan Pekerja Industri Kreatif. Kontan. Retrieved from https://analisis.kontan.co.id/news/menyelamatkan-pekerjaindustri-kreatif

[26] Miles, M. B., \& Huberman, M. (2014). Qualitative Data Analysis: A Methods Sourcebook (3rd ed., Vol. 4). California: Sage Publications.

[27] Moscoso, F. F., Ramirez, J., \& Andrade, N. A. (2014). Economic and Social Affects in the Culture and Arts Industries: The Case of Colombian Festivals. American International Journal of Social Science, 3(2), 43. Retrieved from www.aijssnet.com

[28] Okpara, F. (2007). The Value of Creativity and Innovation In Entrepreneurship. Journal of Asia Entrepreneurship and Sustainability, III(2), $17 . \quad$ Retrieved from http://www.asiaentrepreneurshipjournal.com/AJESIII2Okpara.pd f

[29] Ozaralli, N., \& Rivenburgh, N. K. (2016). Entrepreneurial intention: antecedents to entrepreneurial behavior in the U.S.A. and Turkey. Journal of Global Entrepreneurship Research, 6(1). doi:10.1186/s40497-016-0047-x

[30] Patten, T. (2016). "Creative?"... "Entrepreneur?" - Understanding the Creative Industries Entrepreneur. A Journal of Entrepreneurship in the Art, 5(2), 23-42.

[31] Petrović, D., Milićević, V., \& Sofronijević, A. (2017). Application of Project Management in Creative Industry. European Project Management Journal, 7(2), 59-66.

[32] Rachmawati, A. R. (2020, June 29). 98 Persen Pelaku Industri Kreatif Terdampak Pandemi Covid-19. Pikiran Rakyat. Retrieved from https://www.pikiran-rakyat.com/ekonomi/pr-01580283/98persen-pelaku-industri-kreatif-terdampak-pandemi-covid19 ?page $=2$

[33] Setiaji, S. A. (2020, July 26). Pandemi Covid-19 : Pebisnis Industri 


\section{GENERAL MANAGEMENT}

Kreatif Harus Bisa Manfaatkan Peluang. Bisnis. Retrieved from https://ekonomi.bisnis.com/read/20200726/12/1271282/pandem i-covid-19-pebisnis-industri-kreatif-harus-bisa-manfaatkanpeluang-

[34] Sousa, F. C. de, Nunes, F., \& Monteiro, I. P. (2019). Managers' attitudes to creativity and innovation practices in the creative industries. Tourism \& Management Studies, 15(SI), 33-41. doi:10.18089/tms.2019.15si04

[35] Sugiyono. (2013). Metode Penelitian Kuantitatif, Kualitatif, dan R \& D. Bandung: ALFABETA.

[36] Tresna, P. W., \& Raharja, S. J. (2019). Effect of Entrepreneurial Orientation, Product Innovation and Competitive Advantage on Business Performance in Creative Industries in Bandung City,
Indonesia. Review of Integrative Business and Economics Research, 8(3), 51-60.

[37] Trismiyanto, H. H., Sule, E. T., Joeliaty, \& Yunizar. (2018). The influence of entrepreneurial competence and innovation on performance mediated by opportunities on small handicraft industry craftsmen in West Java. Academy of Strategic Management Journal, 17(6), 1-9.

[38] Yulisetiarini, D., Paramu, H., Hana, S. W. L., Paramita, C., Kristian Suhartadi, W. N., Destari, F., ... Susanto, A. B. (2019). Characterization of creative industries: Challenges and opportunities. International Journal of Scientific and Technology Research, 8(5), 75-77. 